\title{
Towards Inclusive Education: Reconciling Household Obligatory Financing and the Problem of Access to Secondary Education in Cameroon
}

\author{
Prosper Mbelle Mekolle PhD \\ Educational Administration, University of Buea, Buea, Cameroon
}

\begin{abstract}
How to cite this paper: Prosper Mbelle Mekolle "Towards Inclusive Education: Reconciling Household Obligatory Financing and the Problem of Access to Secondary Education in Cameroon" Published in International Journal of Trend in Scientific Research and Development

(ijtsrd), ISSN: 2456-

6470, Volume-3 I

Issue-3, April 2019, pp.1634-1644, URL: https://www.ijtsrd.c om/papers/ijtsrd23 521.pdf

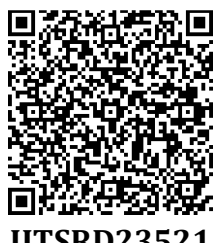

Copyright (c) 2019 by author(s) and International Journal of Trend in Scientific Research and Development Journal. This is an Open Access article distributed under the terms of the Creative Commons

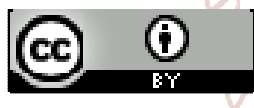
Attribution License (CC BY 4.0) (http://creativecommons.org/licenses/ by $/ 4.0$ )

\section{ABSTRACT}

Current international trends in education provision are tilted towards inclusive practices that place learners at the center of education by valuing their diverse needs, creating a sense of belonging and learning conditions that fosters the success of all. In Cameroon like other SSA countries, a large number of adolescents of secondary school age continue to remain unaccounted for by the educational system due to multifaceted reasons, but largely as a result of systems barriers related to the cost of education and the failure to address the inherent or innate disadvantages and disparities amongst individuals. Very often, policies on compulsory financing are based on grounds that it will augment the stock of educational financing and help close funding gaps. This paper places four key questions at the center of its discussion; questions which require consideration by the government and policy makers: Does the current obligatory financing policies and practices truly constitute an effective means to close the resource gaps that characterizes educational systems? Are there potentials, including under effective governance and management of resources for developing countries secondary education systems to effectively accommodate the educational needs of all without relying on second stream funding to achieve this end? Should the perpetual exclusion resulting from the inability of some individuals to meet the full cost of schooling be overlooked by the state although having a moral duty to fairly distribute existing opportunities or give a chance to all? Does the socioeconomic context of household obligatory financing and the greater need for secondary education to equip large numbers of youths with the skills required to accelerate economic growth towards emergence, in congruence with many developing countries goals, not necessitate an urgent need to revisit and review the current policies? Whatever the case may be, it is imperative that no one is excluded from benefiting from educational services of quality. The paper highlights the experiences and good practices in other developing countries, with significant schooling outcomes. A new policy approach to the financing of an inclusive secondary education project that values the needs of all is suggested in the recommendations.

KEYWORDS: Inclusive Education, Obligatory Financing, Access to Secondary Education

\section{INTRODUCTION}

The success of educational institutions in the conduct of teaching/learning activities depends on the stock of resources at their disposal. In Cameroon like many other countries, money which is used to acquire needed equipment and human resources often come from multiple sources including government budget, external support from development partners, contributions from parents, local community inputs, and school income generating activities in accordance with the legal instruments in force. Although varieties of funding sources exist, in majority of systems, contributions from parents or household obligatory inputs, mainly through enrolment fee, tuition fee and other compulsory levies constitute the main private source of funding for schools operating in both public and private sectors, especially at post primary levels of education. But the use of user charges is as important to schools for quality and sustainability as it is disadvantageous to the many children whose families cannot afford to pay for their schooling. Considering the need to maximize the benefits of education at all levels, its being a basic human right, and the increasing call for countries to eliminate all forms of discrimination and ensure the full participation of all, it is imperative for research to seek ways to reconcile the conflicts of values surrounding the use of household compulsory financing. This is the focus of this paper, with Cameroon at the center of discussion. The paper advances the case for inclusive secondary education, highlights key system's discrepancies and recommends a new policy 
approach to the financing of an inclusive secondary education project that places equal value to the needs of all.

\section{BACKGROUND}

\section{Country context}

Cameroon is a lower-middle-income country in Sub-Saharan Africa (SSA). The country which aspires to reach economic emergence by 2035 stands out as the largest economy in the Central African Economic and Monetary Community (CEMAC) with a population of circa 24.5 million, and an annual growth rate of about 2.6 percent; more than 60 percent are youths under the age of 25 who requires access to basic services such as education. Cameroon is endowed with rich natural resources, including oil and gas, minerals, timber, and agricultural products such as coffee, cotton, cocoa, maize and cassava. The 2019 African Economic Outlook (AfDB, 2019) describes the country's economy as the most resilient in Central Africa in terms of diversification. Agriculture is the backbone of the economy. It employs about 60 percent of the active population and contributed 22.8 percent of GDP in the 2015 (Cameroon NIS, 2017).

Although having abundance of human and natural resources, Cameroon has been unable to record significant economic development, mainly due to the high level of corruption and the weak governance system in place that discourage both national and foreign investors. Cameroon ranked $152^{\text {nd }}$ out of 180 countries in the 2018 Transparency International Corruption Perception Index and 163rd out of 190 economies in the World Bank's 2018 Doing Business report. The country is characterized by high rates of youth unemployment, underemployment, poverty, and inadequacy of basic social services such as education and healthcare, with marked regional and rural-urban disparities. The unemployment rate increased from 3.8 percent in 2007 to 4.3 percent in 2014 , while the underemployment rate increased from 68.7 percent in 2010 to 77 percent in 2014 (World Bank, 2018a). With the creation of thousands of new jobs over the past few years, especially in the public sector, unemployment rate is expected to reduce, but the recent socio-political turn of events in the country stands to challenge this claim.

The activities of Boko Haram in the Far North, the Ex-Seleka rebels in CAR and the armed conflict in the Anglophone regions of the country have interfered with the relative peace and stability which Cameroon has enjoyed in the region for many decades and further aggravated the poverty situation of the country. Poverty rate was 21.8 percent in 2017 based on the international poverty line of $\$ 1.9$ per day (World Bank, 2018b). Poverty affects mainly people living in rural areas and it is particularly concentrated in the crisis-hit regions of the country notably East and Adamawa (30\% and $41.7 \%$ respectively) which hosts about 252,000 refugees from CAR; the northern regions, particularly Far North (74\% altogether) with about 250,000 internally displaced persons (IDPs), 101,000 returnees and 100,000 Nigerian refugees; and recently the two Anglophone Regions (North West and South West) where an ongoing armed conflict have caused the fastest population displacement in Africa in 2018 since it started in late 2017 (OCHA, 2019).

Cameroon had a GDP value of US $\$ 35.0$ billion in 2017 with an account deficit of $2.5 \%$ of GDP, projected to level off at $3.1 \%$ in 2019 and 2020. Real GDP growth rate fell from 5.7 percent in 2015 to 3.5 percent in 2017 but started rising again in 2018 and is forecasted to accelerate to $4.5 \%$ in 2020. While medium term economic prospects are favourable judging from the current growth lens, the future of the country's economy and its security and stability is somehow uncertain and will largely depend on the government's ability to successfully handle the worsening Anglophone crisis as the regions involved house important areas of agricultural production and the country's largest agribusiness-the Cameroon Development Corporation, the largest employer after the state (World Bank, 2018b; AfDB, 2019).

\section{The case for inclusive secondary education}

The second Millennium Development Goal which requires primary education to account for the schooling need of every child irrespective of their backgrounds has today been achieved almost universally. The importance of primary education to the life of the child cannot be overemphasized, however, for individuals and societies to benefit most from education, learning endeavours must go beyond primary schooling. The World Bank (2005) has extensively discussed reasons why countries that have achieve universal primary education or so, but still have low enrolment at the secondary level need to invest in secondary education development. These include contribution to economic growth and poverty reduction, improvements in health and living condition, achievement of the MDGs and the SDGs, realization of democracy and peaceful societies, contribution to growth in primary and tertiary education, etc.

In terms of contribution to economic growth, the World Bank, referencing research by Goldin (1999) notes how secondary education development in the United States between 1910 and 1940 gave the country a half-century lead over European nations that were still lagging in terms of development in secondary education. The Bank also highlights research findings based on analysis of a panel of about 100 countries observed between 1960 and 1995 which showed that economic growth is positively related to the (1960) starting level of average years of adult male school attainment at secondary and higher levels but is insignificantly related to years of primary attainment (Barro, 1999). Besides, the rapid growth which East-Asian countries experienced in the 1970s and 1980s, it has been argued, had much to do with investment in secondary schooling (ADB, 1997). In the same light, many scholars are harmonious in the belief that today's fast growing and competitive economies depend on a workforce that is equipped with knowledge, skills and competencies associated with abstract reasoning, analysis, language and communication, and the application of science and technology-competencies better acquired through secondary education. At the individual level, secondary education is vital for poverty alleviation and income distributional justice to the benefit of people from lower socioeconomic strata by equipping them with knowledge, skills and attitudes which facilitates their absorption into better jobs upon completion of schooling. Although gender-based earning differentials mostly favour males than females for all levels of education, nevertheless, females with secondary education experience are less disadvantaged than those with only primary education level (World Bank, 2009).

Good health is life most important assert and secondary education has been shown to contribute enormously to the 
betterment of individual and family health, in both developed and developing countries. Females with secondary education gets married late relative to those with primary education, and much educated women often give birth to fewer children and tends to adopt better child rearing and family nutrition practices. These in turn leads to lower child and maternal mortality, better education for children, improved family health, and lower population growth. Also, evidence related to HIV infection suggests that those with secondary schooling are less at risk than those with lower levels of educational achievement, both because they are in school and because they are likely to be more receptive to health education messages. Secondary education builds critical thinking skills in young people that enable them to be more prudent about their lives.

For countries that are yet to fully achieve universal primary education, investing in secondary education should facilitate the realization of this goal through its potential to boost completion rates in primary education. It is likely that pupils would be motivated to complete primary schooling if they see the possibility of continuing studies at secondary school level. Secondary education also builds a range of social skills and capabilities that enables individuals to participate effectively in the democratic processes and political life of their societies. It is instrumental in the fight against social vices and for the prevalence of peace and quiet with important financial implications for societies (Mekolle, 2018).

The importance of secondary education highlighted above constitute basis for the ongoing advocacy for expanded coverage which this paper seeks to further. Secondary education expansion need to be prioritized on the education agenda of developing countries, while maintaining appropriate education policies at the primary level as growth in either sector depends on the situation at the other. Historical evidence show that countries that have experienced the most rapid and sustainable increases in educational attainment, as well as outstanding economic performance, have pursued balanced upgrading of the primary, secondary, and tertiary levels of education.

\section{Dynamics in household financing policies in Cameroon (1961-present)}

The decolonization process of Cameroon ended in 1961 when British Southern Cameroons (now North West and South West Regions) gained her independence by joining The Republic of Cameroon-a former French colony that became independent a year earlier. At independence, education was held as the best means to build skills and attitudes in young Cameroonians who would subsequently serve in governance for sustainable progress of the new independent state. This idea was emphasized in the first Five-Year Development Plan (1961-1966) of the federated state, and echoed in the second Five-Year Development Plan (1966-1971). To enhance access, school fee was abolished in all public primary and secondary schools in the country, many being mission schools taken over by the government for the same reason, meanwhile private schools continued to charge fees at various amounts.

The free public education policy lasted for three decades, up to 1992 when it could no longer be maintained having regard to increasing demand for education and the economic crisis that started a few years earlier. As such, Circular Letter no.30/BI/1464/MINEDUC/SG/SAPPS of 2nd November 1992 from the Ministry of National Education sanctioned the payment of school fees in government schools. The need to mobilize educational finances through compulsory levies was subsequently reiterated in other legal instruments containing directives regarding the financing of the education system. Article 5 of Chapter 3 of Decree No. 96/016/PM of 13 February 1996, setting the modalities of application of Law No. 95/010 of 1st July 1995 on the finance act of the Republic of Cameroon for the 1995/1996 fiscal year states that the sources of income of national education shall among others include pupils and students annual compulsory levies, registration fees at all certificate and competitive examinations, examination levies, contribution of beneficiaries to the running cost of education, indemnity paid by pupil/students and the staff for properties damaged by them, and proceeds from sales organized by pupils/students.

Today, general secondary education students pay an annual fee of 7,500FCFA and 10,000FCFA, while those in technical education pay 10,000FCFA and 15,000FCFA for first and second cycles respectively. PTA levy on its part differs from one school to another, and the amounts can be varied yearly even for the same school, depending on the nature of projects planned for the year, but it usually range from $10,000 \mathrm{FCFA}$ to $15,000 \mathrm{FCFA}$, with all students paying the same amount irrespective of their school cycle or grade. In addition to school fees, PTA and other levies, household spend overwhelmingly through purchase of school materials such as uniforms, textbooks, exercise books, school bags, and through provision for transportation, healthcare, meals and rents for accommodation.

For faith-based and lay private institutions, the government has allowed school authorities to charge fee at their discretion. Although schools in this category are entitled to annual public subventions to assist with their major operational costs such as teacher salaries, the amounts are usually small and irregular. As such, because schools tend to rely mainly on tuition and other levies for their operations, the amounts charged are usually very high thereby limiting access mainly to students from households in the highest consumption quintiles who can afford to pay. For the purpose of this paper, two private secondary schools-one typical denominational and the other lay private were studied by the researcher in Fako Division of the South West Region of Cameroon in December 2018 with purpose to determine the nature of cost items and associated charges for none state secondary institutions. In both schools studied, the amounts charged per student per annum varied with grades. Students in the upper grades paid more than those in the lower grades and fees were highest at the second cycle or upper secondary level. The total amount ranged from $356,500 F C F A$ to $391,500 \mathrm{FCFA}$ in the denominational secondary school, and from 51,000FCFA to $82,500 F C F A$ in the lay private institution. These amounts were spread over a number of cost items as shown in the tables below. Total fees did not cover the cost of texts and exercise books which parents have to buy separately, and in lay private schools, the other incidental costs like house rents, transportation and feeding allowances. 
International Journal of Trend in Scientific Research and Development (IJTSRD) @ www.ijtsrd.com eISSN: 2456-6470

Table 1: Annual average charges per education cost item for a typical denominational secondary school in Cameroon

\begin{tabular}{|c|c|c|}
\hline Cost Item & Amounts in FCFA for $1^{\text {st }}$ Cycle & Amounts in FCFA for 2nd Cycle \\
\hline Registration fee & 5,000 & 6,000 \\
\hline Tuition & 100,000 & 115,000 \\
\hline Boarding and meals & 200,000 & 200,000 \\
\hline Internal examination fees & 7,000 & 7,000 \\
\hline FENASCO dues & 2,500 & 2,500 \\
\hline Special subjects practical and other dues & 50,000 & 50,000 \\
\hline Total & 364,500 & 380,500 \\
\hline
\end{tabular}

Table 2: Annual average charges per education cost item for a typical lay private secondary school in Cameroon

\begin{tabular}{|c|c|c|}
\hline Cost Item & Amounts in FCFA for $1^{\text {st }}$ Cycle & Amounts in FCFA for 2nd Cycle \\
\hline Registration fee & 5,700 & 6,500 \\
\hline Tuition fee & 60,800 & 73,000 \\
\hline Others & 6,100 & 8,500 \\
\hline Total & 72600 & 88,000 \\
\hline
\end{tabular}

Textbooks constitute an important schooling requirement. Secondary schools generally operate school libraries, but supplies often fall below the minimum quantity necessary for effective teaching/learning process. Consequently, families are obliged to purchase the textbooks designated by the ministry for a given grade for their children although prices are usually very high and prohibitive. Unit price of primary education textbooks falls between US $\$ 5.5-9$, much higher than US\$1-3 obtained in most comparable countries. Cameroon is therefore classified among the countries with lowest textbook-to-student ratios in the world, averaging 1:14 nationally and reaching as high as 1:30 in some regions (World Bank, 2018a). The following table shows approximated total costs of textbooks in FCFA per grade for the 2018/2019 academic year for general secondary and technical secondary education. Again, household expenses on textbooks are usually separate from the total fee charged by schools, regardless of the type.

Table 3: Total costs of textbooks (approx.) in FCFA for secondary education in Cameroon

\begin{tabular}{|c|c|c|c|c|c|c|}
\hline \multirow{2}{*}{ School Cycle/Grade } & \multicolumn{5}{|c|}{ Lower Secondary } & Upper Secondary \\
\cline { 2 - 7 } & Form 1 & Form 2 & Form 3 & Form 4 & Form 5 & Lower and Upper 6th \\
\hline $\begin{array}{c}\text { Total cost of textbooks } \\
\text { (General Secondary) }\end{array}$ & 36,100 & 35,800 & 62,000 & 57,500 & 43,500 & 52,000 \\
\hline $\begin{array}{c}\text { Total cost of textbooks } \\
\text { (Technical Secondary) }\end{array}$ & 41,200 & 38,600 & 58,000 & 52,800 & 51,000 & 61,000 \\
\hline
\end{tabular}

Source: Adapted from MINESEC Communications No.02/18MINESEC/CAB of 12 June 2018 based on secondary education official textbooks lists for 2018/2019 academic year, and reports from interviews with some technical education school authorities.

In addition to the above expenses, students at the terminal grades of the first and second cycles of secondary education are required to pay for public examination marking their end of course. The unit cost of taking the General Certificate of Education (GCE) examination organized for English-speaking students is presented in Table 4 below.

Table 4: GCE examination cost for Ordinary and Advance Level students in Cameroon

\begin{tabular}{|c|c|c|c|}
\hline \multirow{3}{*}{ Type of Education } & Examination Cost Item & $\begin{array}{c}\text { Cost for Ordinary Level } \\
\text { (in FCFA) }\end{array}$ & $\begin{array}{c}\text { Cost for Advance Level } \\
\text { (in FCFA) }\end{array}$ \\
\hline \multirow{4}{*}{ Technical education } & Registration fee & 8000 & 9000 \\
\cline { 2 - 4 } & Fee per subject & 1000 & 2000 \\
\cline { 2 - 4 } & Practical fee per subject & 5000 & 5000 \\
\cline { 2 - 4 } & Specialty practical fee (industrial) & 12000 & 12000 \\
\cline { 2 - 4 } General education & Franking of form B3/G3/T3 & 1000 & 9000 \\
\cline { 2 - 4 } & Registration fee & 8000 & 2000 \\
\cline { 2 - 4 } & Fee per subject & 1000 & 5000 \\
\cline { 2 - 4 } & Practical fee per subject & 5000 & 1000 \\
\hline
\end{tabular}

Source: Cameroon GCE Board DecisionsNo.0406/A/2018/GCEB/DRE/ED-ALT/EO-OLT and No.0406 /B/2018/GCEB/DRE/EO-OLG/EO-ALG of 18 December 2018 bearing on information to candidates for the 2019 registration

Expenses on examination when put together, are often fairly large considering the fact that candidates are required to register from 5-11 subjects for Ordinary Level, while those for Advance level register 3-5 subjects per session of the examination. The same applies to the total expenses incurred by households to educate each child over a given school year. The findings of the Fourth Cameroonian Household Survey (Cameroon NIS, 2014) that held in 2017 shows that in the
2013/14 school year, household spending national average were only a little less than 50,000 FCFA (US\$102) per student at the secondary level. Averages were 29,000 FCFA among public schools, and 99,000 FCFA among private schools. No significant difference existed in spending levels between the Francophone and Anglophone education subsectors, but marked difference were noted across the ten regions, with families in the wealthier center, Littoral and 
South West Regions spending much more per child than families in the poorer Northern Regions.

At the primary sector, a Presidential declaration of February $10^{\text {th }}, 2000$ abolished school fees in public primary schools as policy strategy to boost enrolment towards universal primary education. However, and in addition to where fee is paid, parents purchase school materials such as uniforms and books, provide transportation, healthcare, meals, and pay for registration and examination. At the higher education level, a Presidential decree introduced the payment of fees from the 1991/92 academic year. Students attending the eight state universities and some higher professional training institutions pay a registration fee of 50,000 FCFA per annum plus other charges, but the amount are much higher for some special professional courses at the postgraduate level. In private higher institutions, the amount of tuition ranges between 250,000 FCFA to about 800,000 FCFA per student per annum depending on institutional type, programmes and level of study.

From the forgoing analysis, it can be seen that households in Cameroon incur considerable expenditures for the education of their children. Compared to what obtains in developed countries where compulsory education is free up to upper secondary level, in most developing countries, households spend enormously in education financing at all levels. Their contributions have been measured at some points to equal, or even outweigh public expenditure. Data for SSA for instance shows that between 2001 and 2006, households contributed $49 \%$ of total expenditure for lower secondary and $44 \%$ of total expenditure for upper secondary education, meanwhile $51 \%$ and $56 \%$ respectively came from public and other private sources during the same period (UNESCO, 2011). Wherever households spend more on education, their action does not imply willingness to pay, but rather the compulsory need to do so. "Families feel compelled to spend on education as governments do not spend adequately on providing education, quality teachers, textbooks and stationery, libraries, and other incentives and student welfare activities" (UNESCO, 2013: 21).

Policies on user charges and other household obligatory financing of education in developing countries were informed mainly by World Bank's recommendations calling on governments to explore alternative ways of financing education in the face of limited public resources and growing demand for school places. Tembon (1994) points out a number of earlier studies financed by the Bank with focus, inter alia, on the possible introduction of user fees at the primary and secondary levels of education as a way of cost sharing with households, and a means to source the much needed additional funding. She notes that the researchers of the studies drew conclusions in favour of the imposition of school fees, on grounds that people will pay and the resources generated would help to improve the quality of education and also increase the supply of school places for more student intake. The studies further recommended the use of government subsidies that targets the poor or those who cannot afford fees and other user charges in order not to exclude these from benefiting from education services. Generally, the argument for cost sharing is centered basically on the need for efficiency in education. Proponents opine that effective assumption of the financial burdens by students is instrumental in reducing the problem of resource wastage. The view is that students who pay directly for their studies are likely to make efficient use of resources, attach more value to their education and take learning activities seriously, while those who receive relatively highly subsidized education, especially rich students are likely to be wasteful. Other schools of thoughts submit that institutions tend to serve political interest than give attention to students' needs where education is funded solely by the state, and that schools tend to be more efficient under calls for more accountability by interest groups such as families and communities when these contribute to educational financing.

\section{Questions for Consideration}

Cost sharing policies are efficient in countries where the government encourage private financing by demonstrating strong commitment to educational development through adequate public spending on education, and where household are economically empowered so that they ambitiously complement public expenditure. The issues requiring reflection by Cameroon and other SSA governments who owes the responsibility of providing education to their citizens and which are of concern to this study are four folds: Does the current obligatory financing policies and practices truly constitute an effective means to close the resource gaps characteristic of country educational systems? Are there potentials, including under effective governance and management of resources for developing countries secondary education systems to effectively accommodate the educational needs of all qualified students without relying on second stream funding to achieve this end? Should the perpetual exclusion resulting from the inability of some individuals to meet the full cost of schooling be overlooked by the state although having a moral duty to fairly distribute existing opportunities or give a chance to all? Does the socioeconomic context of household obligatory financing and the greater need for secondary education to equip large numbers of youths with the skills required to accelerate economic growth towards emergence, in congruence with many developing countries goals, not necessitate an urgent need to revisit and review the current policies? Answers to these questions are highly imperative, especially having regard to some peculiar evidence in the literature. A study conducted in Ghana (Penrose, 1998) found that cost sharing with households did not improve educational quality, rather it contributed to a drop in enrolment at secondary level and it did not augment educational resources in a real sense.

\section{STATEMENT OF THE PROBLEM}

Inclusive and equitable quality education is widely recognized as the most effective means to improve the lives and future prospects of every individual and society on earth. On the basis of this understanding, world leaders, meeting at the third session of the UN General Assembly in 1948 in Paris, France, declared education as a basic human right (Article 26), among the other inalienable entitlements of every human being contained in the Universal Declaration of Human Right (Resolution 217A) proclaimed by the assembly. The human right factor of education and the need for states to avoid all forms of discrimination and adopt policies that promote growth of the sector and universalization of access to account for the needs of all persons has been stated in a number of subsequent international instruments. These include the 1959 United Nations Declaration of the Rights of the Child (Principle 7), 1960 UNESCO Convention against Discrimination in 
Education (Article 4), and the 1989 United Nations Convention on the Rights of the Child (articles 29 and 30) among others. With respect to secondary education, Article 13(2b) of the UN International Covenant on Economic, Social and Cultural Rights states that "secondary education in its different forms, including technical and vocational secondary education, shall be made generally available and accessible to all by every appropriate means, and in particular by the progressive introduction of free education". These provisions have been ratified by the Cameroon government and further echoed in the country's constitution and other legal instruments.

Although much has been said to this regard, Cameroon and other SSA countries' governments continue to demonstrate inadequate commitment towards inclusive secondary education as reflected by the lack of consideration for expansion in their Poverty Reduction Strategy Papers and other policy documents. In Cameroon, although government education spending prioritizes the secondary level, total spending on education in proportion to the national budget over the past two decades has been slightly below the most recent available SSA average of 16.6 percent recorded in 2013. It shrank from 14.6 percent of the national budget in 2014 to 12.5 percent in 2016; far below the 20 percent Education Sector Strategy planned spending mark. Besides, most of the education budget is devoted to operational spending, particularly teacher salaries, with relatively little assigned for investment. This phenomenon leads to the educational system in turn devoting little amounts of resources for school supplies and facility upgrade and expansion, with negative implications for education quality and student intake (World Bank 2018a).

As a result, SSA continue to remain home for a large majority of the world's out-of-school children, many of them being youths of secondary school age (approx. 12-18 years) and mainly girls. Although factors such as domestic responsibilities, sexual harassment, unwanted pregnancy, socio-cultural biases and early marriage contributes to poor enrolment, poverty and consequently lack of resources to meet up with user charges and other schooling needs constitute main cause of exclusion. Of all comparative variables, income was associated with the biggest disparity among youths of secondary school age who were out of school; 44 percent came from the poorest quintile, compared to only 9 percent from the richest quintile (Education Policy and Data Center, 2018). Exclusive secondary education and inequity in access constitute a major barrier human development, economic growth and poverty reduction. It is therefore necessary that Cameroon and other SSA countries' governments demonstrate greater commitment towards expansion of secondary education coverage to provide every individual the equal opportunity to reach their greatest potential, and to enhance the achievement of planned national development goals. To do so require the elimination of financial barriers that directly or indirectly impedes access to secondary education services for students from poor communities, ethnic minorities, indigenous people and other disadvantaged groups.

\section{CONCEPTUAL REVIEW Obligatory Contributions}

Directly or indirectly (through opportunity costs), households pay for the overwhelmingly largest share of total private financing. Obligatory contributions constitute expenses that families must make because their children are in school. Tuition fees is perhaps the most common form of obligatory financing as it usually applies to all enrolled pupils and students. It refers to the money pupils and students pay for receiving teaching services. Generally, apart from fees paid for tuition, households pay other educational charges such as PTA levies, examination fees, books, school uniforms and also provides for such needs as children's accommodation, meals, transportation, etc. The money spent by households on the education of children usually comes from three main sources including remittances, educational loans and family income.

\section{Remittances}

Remittances include monetary transfers from oversea nonresident and resident individuals to their families and friends back home, or to countries other than where they currently reside, for mainly investment purposes. Remittance constitutes an important resource and makes up a significant share of GDP, particularly in lower middle income countries (LMICs) and low-income countries (LICs), as families here increasingly send their children to economically more advanced countries for greener pastures. World Bank estimates shows that in 2017 for example, the share of GDP which came from personal remittances in LMICs such as Ghana, Lesotho and Senegal stood at $6.0 \%$, $15.6 \%$ and $10.6 \%$ respectively. Cameroon received $0.9 \%$, much lower than the average (4.10\%) for LMICs. Available data also shows that some countries are heavily dependent on personal remittances, with about 25 countries having inflows exceeding $10 \%$ of GDP in 2015.

It is difficult to be precise on the percentage of educational inputs that comes from remittances due to the scarcity of data. However, remittances constitute an important source of obligatory financing in most developing countries. With scarce resources and opportunities at home, many school children depend entirely on remittances for their education and healthcare services. A study of the impact of remittances on health and education outcomes in 18 SSA countries revealed that migrant remittances have significant positive impacts on secondary education outcome. Increasing remittances by 10 percent will on the average, increase secondary education outcome by 8.8 percent (Amakom \& Iheoma. 2014). Calero et al. (2009) also shows that in Ecuador, the receipt of remittances increased school enrolment for children, especially for girls in rural areas. The problem with remittances has to do with the negative, mainly psychological effects of migration on children's schooling, especially when it concerns the migration of a close relative.

\section{Loans}

Like public sources of financing, in many countries, obligatory contributions by households and students also comes from educational loans. Money used to sponsor children in schools can be borrowed from government financial institutions or from private financial institutions and cooperatives. A review of international experience of student loan found official loan programmes that are run by government agencies or backed by government guarantees in more than thirty countries (World Bank, 2008). In fact, the use of educational loans is becoming a worldwide trend, especially at the level of higher education. In many developed ones, students are given what is referred to as income contingency loans to help finance their education on 
condition that repayment would be done when they start earning an income.

Loan schemes have been praised for their role in enhancing quality, equity, and efficiency of the education system, as well as the overall management of the sector. They provide opportunities for access to education to poor students who find it difficult to pay upfront and so often excluded from education. They also motivate and increase the level of commitment of beneficiaries to their studies since they understand the obligatory need to repay the debts in future. Higher education loans create the possibility for governments to limit spending on higher education and reallocate more resources for secondary and primary education expansion and improvement. However, much effort is usually required by loaners for beneficiaries to repay back the loans especially where collaterals are not requested and the use of loans have been observed to have a minimal effect on increase in students enrollment compared to student grants.

\section{Family income}

Family income constitutes the most fundamental source of obligatory financing. Annual incomes are often used as the criteria for socio-economic classification of households into quintiles from the poorest to the riches, whereby we have the $1^{\text {st }}$ quintile which constitute the poorest $20 \%$, followed by the $2^{\text {nd }}$ quintile, $3^{\text {rd }}$ quintile, $4^{\text {th }}$ quintile and the $5^{\text {th }}$ quintile which comprise the richest 20\%. Household expenditure on education varies and depends more on the socio-economic group to which they belong: the poorer the family, the greater the burden of education financing. Data for Cameroon shows that in 2001, the proportion of households' disposable income spent on education by income quintile was as follows: $3.8 \%$ for the $1^{\text {st }}$ quintile, $4.9 \%$ for the $2^{\text {nd }}$ quintile, $5.7 \%$ for the $3^{\text {rd }}$ quintile, $7.2 \%$ for the $4^{\text {th }}$ quintile and $8.1 \%$ for the $5^{\text {th }}$ quintile (UNESCO, 2011). These spending patterns can be explained in many ways. Children from lowest-income families often do not go beyond basic education where schooling is often tuition free or less expensive. They also tend to attend public or community schools where charges are comparatively lower. Therefore, education expenditure among poor families is mainly on unavoidable items like materials associated with attending school and school supplies. On the other hand high income earning families that often send their children to more prestigious and expensive institutions and up to higher education spend more on education in terms of tuition fees, school supplies, private tutoring, etc. Nevertheless, low income families in an effort to maximize the benefits of education and improve upon their socio-economic status sometimes arrive at decision whereby they sacrifice a larger share of their incomes to provide quality education to their children right up to the level of higher education. In such instances, the relationship between household incomes and expenditures on education becomes negative so that families that are lower on the socio-economic scale spend a higher percentage of their income on education than those higher on the scale as observed in Cameroon (World Bank 2018a).

Payment of schools fees, PTA levies, examination fees and other school charges to educational institutions by students and their families constitutes more direct obligatory forms of private financing. Apart from these, parents are obliged to finance education through other informal means such as payment for private supplementary tutoring which is common practice in Cameroon and other developing countries. In Uzbekistan for example, private tutoring is reported to be the second largest education cost item for households (UNESCO, 2013). Students and households pay for private tutoring directly to the individual tutor or to a group of teachers depending on who is involved and how the practice is organized at the supply side

Obligatory household contributions are generally perceived as a very reliable private source of educational financing. However, this means of financing education skew disproportionally on lower and middle income families as it tend to take a greater share of their income, especially where expenditure on education is not subsidized by the government. As such and unless accompanied by carefully selected policies, obligatory contributions often leads to exclusion of children from poor households thereby perpetuation of the gap between the rich and the poor.

\section{Inclusive Education}

The term inclusive education has frequently appeared in educational discourse and policy documents ever since the wake of the disability movement from which it got its roots. However, scholars, governments and other educational stakeholders in different countries vary in opinion as to what comprises inclusive practices in education. Some view it solely from the perspective of acceptance and participation of persons with disabilities or special educational needs in mainstream schools, while to others, it encompasses school coverage of the economically unprivileged students and persons from rural and marginalized communities. But there are more barriers to learning that begs for redress other than the conventional ones. Learning barriers are usually intrinsic or extrinsic in nature, or both, and may include age, gender, ethnicity, language, health status, etc. For better understanding and to avoid misconstructions which often lead to misguided educational policies and system underperformance, it is imperative to attempt an in-depth conceptualization of inclusive education. Inclusive education has to do with the full and equal participation of all individuals to quality educational opportunities irrespective of their pre-entry or actual disadvantaged conditions. It requires that the educational system corrects the inherent or innate disadvantages and disparities amongst individuals through the indiscriminate provision of quality learning opportunities that enables everyone reach their greatest potential. The following excerpt drawn from the operational guideline for inclusive schools as prescribed by The Salamanca Statement and Framework for Action on Special Needs Education (UNESCO \& MES, 1994) highlights the main aspects of inclusive education.

schools should accommodate all children regardless of their physical, intellectual, social, emotional, linguistic or other conditions. This should include disabled and gifted children, street and working children, children from remote or nomadic populations, children from linguistic, ethnic or cultural minorities and children from other disadvantaged or marginalized areas or groups...Inclusive schools must recognize and respond to the diverse needs of their students, accommodating both different styles and rates of learning and ensuring quality education to all... (pp. 6, 11-12).

According to the National Council for Special Education (NCSE, 2011), inclusion in education is a process that has to do with: 
$>$ Addressing and responding to the diversity of needs of learners through enabling participation in learning, cultures, and communities and,

$>$ Dismantling the barriers to access to education, and within education through the accommodation of all students and provision of appropriate structures and programmes to enable each learner achieve the maximum benefit from his/her schooling.

Inclusive educational systems avoids discrimination of any kind, whether within or outside the school system. It transcends integration (the accommodation of all persons within the corresponding school age group by the educational system irrespective of their backgrounds), to learner-centered education, and is concerned with the maximum participation and academic achievement of all students. In other words, it places equal priority to the wellbeing of all students, with quality as the yardstick of operation. This usually necessitates that the educational system strengthen partnership with communities and undergo transformation or adjustments through the diversification of school curricular and learning materials, teaching strategies, provision of remedial services, adoption of multiple assessment practices, and adjustment of academic timetables to carter for the diverse needs of learners.

Educational systems that do not exhibit inclusive values are discriminatory or exclusive in nature. They are characterised by discrimination against students of certain social conditions, disabilities, ethnic origin, cultural backgrounds, gender, sexual orientation, etc. These biases are experienced by students on a daily basis in different school systems across the world. Such systems also suffer low transition rates to succeeding grade and levels, high rates of repetition, out-of-school youths and dropout, high disparity in enrolment with regard to gender, location and socioeconomic situations, low quality of inputs and services and poor learning outcomes. This is common with educational systems in developing countries. Discussing on the achievement of basic skills taught at the primary level of education, the UN notes that even though more children than ever are going to school, many do not acquire basic skills; only about half of students at the end of primary education attained minimum proficiency levels in reading or mathematics in many countries in SSA and Latin America and the Caribbean between the period 2007-2015 (UN, 2017). The results of the 2014 Programme for the Analysis of Education Systems, known in its French acronym as PASEC (Programme d'Analyse des Systèmes Éducatifs de la Confemen) -a standardized test administered to second and sixth-grade students in French-speaking countries all over the world shows that just over 50 percent of Cameroons' sixth-grade students scored above "sufficient" in language, while nearly one-quarter scored in the two lowest levels. Sixth-grade students scored below average for mathematics, with close to 65 percent of the candidates scoring in the two lowest levels (PASEC, 2016).

These traces of exclusion in primary education in developing countries coupled with the lows in enrolment in secondary and higher education, poses a great challenge to the achievement of the goal of inclusive primary and secondary education as set forth in SDG number 4. The need for developing countries to adopt and accord privilege position to policies that aim towards a system of mass secondary education is of immediate importance. Such a system must be responsive to countries' socioeconomic needs and capabilities, should be able to retain all enrolled students and effectively satisfy their diverse needs, and should help school leavers acquire the knowledge, skills, attitudes and experiences needed to exercise their choices beyond secondary education (World Bank, 2005).

\section{THEORETICAL UNDERPININGS}

The growing advocacy for inclusive education which has characterized educational discourse and global policy over the past few decades have been rested mainly on the paradigms which holds that human rights and social justice claim should occupy central place in educational endeavours. This study adopts the social model of disability and the postulation of access theory which suggests that 'ability' rather than 'right' or 'entitlement' is what guarantees benefits from things.

The social model of disability focuses on the systemic barriers which prevents people from participating in the society and seeks to know what can be done to dismantle barriers to inclusion. The model holds societal attitudes as the main problem to access to services for the disabled. For example, the way organizations produce information; conforming only to how it suits the use or interest of the majority rather than offering it in variety of formats such as braille and large texts, etc. to equally serve the needs of the visually impaired. People with impairment or disability are therefore disabled by the way societies treat them and not because they cannot engage in certain actions or achieve certain goals under their respective conditions. In education, barriers to learning and participation are created by society to the detriment of people who do not conform to the expectations of the majority in terms of appearance, behaviour and/or socioeconomic situation (Lorna, 2017). An inclusive education system must recognize individuals' uniqueness and differences in circumstances and experience, and strive to provide appropriate solutions to their respective challenges to ensure equitable participation.

Access theory looks at how individuals benefit from things, including those in the hands of other individuals in complex social relationships. It shifts from the theoretical constructs that views 'right' as basis to derive benefit from things, to 'ability' to do so, with the argument that a person may be entitled to certain rights but unable to enjoy them due their relative position vis-à-vis the good or service (Ribot \& Peluso, 2003). An individual may have the right to education, but may be physically, emotionally or financially impaired from accessing educational services. The theory suggests the need for those who wield power over education to treat education not just as a human right, but to equally provide enabling conditions for access to inclusive education services.

\section{EMERGING GOOD PRACTICES IN SOME DEVELOPING COUNTRIES: THE CASE OF THAILAND AND KENYA}

Although progress in secondary education development and coverage in developing countries is generally slow compared to most developed countries at the time when they were at the same level of economic development, notwithstanding, many countries are progressively giving attention to the importance of inclusive practices, and the need to enhance the full participation of all, with special consideration for the socioeconomically disadvantaged groups. In brief, 
compulsory secondary education is gradually becoming the norm. Cameroon could be commended for the large and growing government allocation to secondary education-49 percent of the education budget in 2017, compared to the average for SSA countries measured at 32 percent in 2009 , but the potential effects of such allocation are watered down by the inefficiencies associated with financial allocations and management policies within the system. Therefore, unlike other developing countries in the world, Cameroon is yet to adopt measures that target individual specific access challenges. A look at some good practices associated with growth evolution in other developing countries could help revitalize the country's secondary education system as was during the period after independence.

\section{Thailand}

Thailand is an upper-middle income country in Southeast Asia with a population of about 67.2 million. The country operates a less complex educational management structure which permits resources to be allocated efficiently in a way that targets only priority areas. Although the Office of the Prime Minister, Ministry of Education and Ministry of the Interior have the mandate, the responsibility of educational management at all level is shouldered by the Ministry of Education which also provides non-formal education programmes and supervises private educational institutions at all levels. Compulsory education runs from primary to lower secondary level, and is centered on a basic education common core curriculum that comprises eight core areas of learning which progressively sophisticate towards higher grades up to upper secondary education.

The Thai constitution requires the government to provide a minimum of 12 years of free basic education of quality. The policy was started in October 2002 and included primary and secondary education (6 years each). In May 2004, free basic education was extended to 14 years to cover 2 years of pre-primary schooling, and it is now offered for 15 years, with upper secondary education included, following a modification of the policy in 2009. The new policy accords special attention to the needs of poor children and students from other disadvantaged groups. Items provided to students as part of free education include tuition fees, textbooks, learning materials, school uniforms, among others, and actual implementation process follows welldefined strategies and criteria (including as concerns subsidies for private schools) that involves the participation of stakeholders across the board. These policies have led to high rate of secondary school enrolment and transition rates from lower to upper secondary levels (UNESCO, 2011).

\section{Kenya}

Kenya population was estimated at 45.4 million in 2016 . The country, like many developing ones, has a very youthful population. Government's commitments center on national development priorities that impact the education and training sector through Vision2030, the successive implementation of the medium-term plans, and the "Big 4" agenda. Educational financing involves various stakeholders, but the national budget constitutes the main source of funding. The actual values of public allocations to the education sector have increased over the years, although it has declined as a percentage of total public spending.

In January 2008, the government of Kenya launched Free Day Secondary Education (FDSE), barely 5 years after launching Free Primary Education. The policy was introduced in recognition of the negative bearing that low transition rate to secondary schools, mainly due to high costs of schooling at that level, had on the achievement of Education for All targets and the MDGs. It was therefore designed to address discrepancies such as cost of education, illiteracy, low completion rates at the secondary level, large gender and regional disparities in participation, and poor community involvement. FDSE covers tuition fees, while parents finance school development projects and provide for children's other schooling needs like uniforms, learning materials, feeding, transportation and boarding fees for students in boarding schools. The Ministry of Education allocates and disburses the FPE and FDSE capitation grants directly to schools based on individual school enrolment numbers. Also, a Constituency Bursary Fund Committee identifies needy students for whom bursaries are provided at respective schools and tertiary institutions so that no one who qualifies would be excluded because they cannot meet up with schooling costs. With regards to textbooks, the government has centralized procurement with goal to improve availability of textbooks and instructional material in both primary and secondary schools. Free basic and subsidized education policies have significantly improved access and transition in Basic Education (Republic of Kenya, 2018).

Other examples can be cited in South Africa, Ghana, the Gambia, Uganda and Tanzania that uses free tuition fee policy and other incentives in secondary education. In Bangladesh, secondary education has been made free for girls, the same like in some states in India. In Mongolia, 60\% of the textbook costs incurred by disadvantaged families are compensated by the government. And in countries such as Nepal, additional classrooms are belt next to primary schools to operate junior secondary education. This practice facilitates the transition from primary to lower secondary education and minimize drop out for both physical and geographical reasons (UNESCO, 2013).

\section{CONCLUSION AND RECOMMENDATIONS}

The central thesis has been that inclusive quality education for all is critical for human empowerment and promotion of economic prosperity and societal wellbeing. To this regard, improvements in secondary education have been made in many countries in the world in a way that suits their various national needs. Today's international trends indicates that countries are shifting towards inclusive practices and childcentered approaches to secondary education provision that recognizes diversities, places equal value to individual student needs, and seeks to enhance the full participation of all. Developing countries are increasingly providing free and compulsory secondary education, with concerns of access, equity, quality and relevance occupying central position in education and training agenda. While it is important for governments to increase household and community participation in educational endeavours, it is imperative that no child is denied access to secondary education on the basis of inability to pay school fees or meet up with other schooling needs. Consequently, compulsory levy policies at primary and secondary levels of education, whether in the public or private sector should be seen as increasingly becoming obsolete and government efforts should be directed towards adopting more liberal and progressive financing policies that embrace the diverse schooling challenges of learners. Workable strategies used in other 
nation could inform such policies and bring about the required growth in secondary education. This paper makes five key recommendations directed towards reducing the costs of schooling for all and enhancing full participation. All recommendations are feasible having regard to Cameroons economic outlook and national demographic features. All that is required is adequate commitment and efficient allocation and management of resources within the educational system, and across all sectors of the economy.

$>$ Education should be provided free of charge at least at the lower secondary level. This would make secondary schooling more affordable and increase the participation of the poor, vulnerable and the marginalized groups, particular those in the Eastern and Northern regions of the country, as well as the conflict affected Anglophone regions. Free secondary education could start by eliminating the school fee factor and then progressively cover other cost items such as textbooks and school uniforms. An increase in secondary education investment budget for the expansion of structures and materials is highly recommended.

$>$ Adopt a more affordable and sustainable textbook policy. Textbooks for core subject areas should be harmonized across all levels of education. The current drive towards a more sustainable textbook policy of one textbook per subject for a lifespan of six years is highly encourages and should be effectively commenced. These in turn would foster economies of scale and significantly reduce the burden on parents.

$>$ Adopt a progressive education tax on incomes and business profits. Free secondary education would require increase in government spending on education to carter for student influx and to keep with the need for quality. An educational tax on the incomes of all workers and business profits that exempt the poor and marginalized groups would be an effective means to increase the participation of the broader community in the financing of free secondary education.

$>$ Bring secondary education closer to children. Education at any level may be provided free of charge but if schools are not located within safe travel distances, many children will end up not enrolling or effectively participating, especially females. The government is therefore encouraged to come up with a policy of mass enrolment that builds more schools in the underserved regions and rural communities to reduce the high costs incurred by parents in sponsoring children in schools far from home.

$>$ Establish flexibility in schooling schedules where necessary. Formal schooling regulation and schedules are often inappropriate for students in rural areas who have to assist their family during certain periods of the day or certain months in the year as the case is in the Northern regions of the country. Establishing flexibility, including through double shifts should be considered where necessary and as the means may provide.

\section{REFERENCES}

[1]. ADB. (1997). Emerging Asia: changes and challenges. Manila: ADB.

[2]. AfDB. (2019). African economic outlook 2019. Abidjan: AfDB.

[3]. Amakom, U. and Iheoma, C. G. (2014). Impact of migrant remittances on health and education outcomes in Sub-Saharan Africa. Journal of Humanities and Social Science, 19(8), 33-44.

[4]. Aslam, M. and Atherton, P. (2011). The "shadow" education sector in India and Pakistan: The determinants, benefits and equity effects of private tutoring. Presentation at the United Kingdom Forum for International Education and Training Conference, University of Oxford, 13-15 September.

[5]. Barro, R. J. (1999). Human capital and growth in crosscountry regressions. Swedish Economic Policy Review, 6(2), 237-77.

[6]. Calero, C., Bedi, A. S., and Sparrow, R. (2009). Remittances, liquidity constraints and human capital investments in Ecuador. World Development 37(6), 1143-1154.

[7]. Cameroon NIS. (2014) Fourth Cameroonian household survey (Quatrième enquête Camerounaise auprès des menages: ECAM 4. Republic of Cameroon.

[8]. Cameroon NIS. (2017). Statistical Yearbook 2017 (ed). Republic of Cameroon.

[9]. Cox E.A. and Ureta, M. (2003). International migration, remittances, and schooling: evidence from El Salvador. Journal of Development Economics, 72(2), 429-461.

[10]. Education Policy and Data Center. (2018). Cameroon national education profile 2018. Washington, D.C.: Education Policy and Data Center.

[11]. Goldin, C. (1999). Egalitarianism and the returns to education during the great transformation of American education. Journal of Political Economy, 107(6), S65S94.

[12] Lewin, K. M. and Caillods, F. (Eds.) (2001). Financing secondary schools in developing countries: Strategies for sustainable growth. Paris: UNESCO International Institute for Educational Planning.

[13]. Lorna, M.D. (2017). Inclusive Education. In Ramrathan, L., Le Grange, L. and Higgs, P. (Eds.), Education for initial teacher training (pp. 383-400). Cape Town: Juta \& Company (Pty) Ltd.

[14]. Mekolle, P.M. (2017). Decentralization and the financing of access to secondary education in Ccameroon: Community contributions counts? European Journal of Education Studies, 6(2), 82-99.

[15]. NCSE. (2011). Inclusive Education Framework: A guide for schools on the inclusion of pupils with special educational needs. Mill Street, Trim: NCSE.

[16]. OCHA, (2019). Cameroon: Humanitarian Response Plan 2019. OCHA: Cameroon.

[17]. PASEC (2016). PASEC2014 - Performances du système éducatif Camerounaise: Compétences et facteurs de réussite au primaire. Dakar: CONFEMEN.

[18]. Penrose, P. (1998). Cost sharing in education - public finance, school and household perspectives. Education Research Paper No. 27. Cornwall: Penquite House.

[19]. Republic of Kenya (2018). Comprehensive public expenditure review: From evidence to policy, 2017. Kenya: Government of the Republic of Kenya. 
International Journal of Trend in Scientific Research and Development (IJTSRD) @ www.ijtsrd.com eISSN: 2456-6470

[20]. Ribot, J. C. and Peluso, N. L. (2003). A theory of access. Rural Sociology, 68(2), 153-181.

[21]. Tembon, M. M. (1994). The financing of secondary education in Mezam Division, North West Province of Cameroon: An uneasy partnership between family and state? London: University of London.

[22]. UN. (2017). The Sustainable Development Goals Report 2017. New York: U.N.

[23]. UNESCO \& MES. (1994). The Salamanca Statement and Frameworkfor Action on Special Needs Education. Paris: UNESCO.

[24]. UNESCO (2011). Financing education in Sub-Saharan Africa: Meeting the challenges of expansion, equity and quality. Quebec: UNESCO Institute for Statistics.

[25]. UNESCO (2013). Financing of secondary education in the Asia-pacific region. Education Policy Research Series Discussion Document No. 4. Bangkok: UNESCO.

[26]. UNESCO-IBE (2011). World data on education Thailand ( $7^{\text {th }}$ ed.). Bangkok: UNESCO-IBE

[27]. World Bank (2008). Project appraisal document; science and technology higher education program, Tanzania. Washington, D.C.: World Bank.
[28]. World Bank (2009). Secondary Education in India: Universalizing opportunity. Human Development Unit, South Asia Region.

[29]. World Bank. (2005). Expanding opportunities and Building competencies for young people: A new agenda for secondary education. Washington, D.C.: World Bank.

[30]. World Bank. (2018a). Cameroon public expenditure review: Aligning public expenditure with the Goals of Vision 2035. Washington, D.C.: World Bank.

[31]. World Bank. (2018b). Sub-Sahara Africa macro poverty outlook: Country-by-country analysis and projections for the developing world. Washington, D.C.: World Bank.

[32]. http://data.worldbank.org/indicator/BX.TRF.PWKR.D T.GD.ZS. Viewed on 11/04/19

[33]. https://www.epdc.org/education-dataresearch/cameroon-national-education-profile-2018. Viewed on 14/03/19

[34]. https://www.humanitarianresponse.info/en/program me-cycle/space/document/cameroon-plan-deresponse-humanitaire-2019

[35]. https://www.worldbank.org/en/country/Cameroon, viewed on $30 / 03 / 19$ 